\title{
Unraveling the roles of the reductant and free copper ions in LPMO kinetics
}

\author{
Anton A. Stepnov ${ }^{1}$, Zarah Forsberg ${ }^{1}$, Morten Sørlie , Giang-Son Nguyen², Alexander Wentzel², Åsmund K. Røhr ${ }^{1}$ \\ and Vincent G. H. Eijsink ${ }^{1 *}$ (D)
}

\begin{abstract}
Background: Lytic polysaccharide monooxygenases (LPMOs) are monocopper enzymes that catalyze oxidative depolymerization of industrially relevant crystalline polysaccharides, such as cellulose, in a reaction that depends on an electron donor and $\mathrm{O}_{2}$ or $\mathrm{H}_{2} \mathrm{O}_{2}$. While it is well known that LPMOs can utilize a wide variety of electron donors, the variation in reported efficiencies of various LPMO-reductant combinations remains largely unexplained.
\end{abstract}

Results: In this study, we describe a novel two-domain cellulose-active family AA10 LPMO from a marine actinomycete, which we have used to look more closely at the effects of the reductant and copper ions on the LPMO reaction. Our results show that ascorbate-driven LPMO reactions are extremely sensitive to very low amounts (micromolar concentrations) of free copper because reduction of free $\mathrm{Cu}(\mathrm{II})$ ions by ascorbic acid leads to formation of $\mathrm{H}_{2} \mathrm{O}_{2}$, which speeds up the LPMO reaction. In contrast, the use of gallic acid yields steady reactions that are almost insensitive to the presence of free copper ions. Various experiments, including dose-response studies with the enzyme, showed that under typically used reaction conditions, the rate of the reaction is limited by LPMO-independent formation of $\mathrm{H}_{2} \mathrm{O}_{2}$ resulting from oxidation of the reductant.

Conclusion: The strong impact of low amounts of free copper on $\mathrm{LPMO}$ reactions with ascorbic acid and $\mathrm{O}_{2}$, i.e. the most commonly used conditions when assessing LPMO activity, likely explains reported variations in LPMO rates. The observed differences between ascorbic acid and gallic acid show a way of making LPMO reactions less copperdependent and illustrate that reductant effects on LPMO action need to be interpreted with great caution. In clean reactions, with minimized generation of $\mathrm{H}_{2} \mathrm{O}_{2}$, the $\left(\mathrm{O}_{2}\right.$-driven) LPMO reaction is exceedingly slow, compared to the much faster peroxygenase reaction that occurs when adding $\mathrm{H}_{2} \mathrm{O}_{2}$.

Keywords: Lytic polysaccharide monooxygenase, AA10, Enzyme kinetics, Hydrogen peroxide, Copper, Ascorbic acid, Gallic acid

\section{Background}

Lytic polysaccharide monooxygenases (LPMOs) are monocopper enzymes that catalyze oxidative cleavage of polysaccharide substrates, such as chitin and cellulose [1-4]. The LPMO active site is formed by two conserved histidine residues coordinating a copper ion in a

\footnotetext{
*Correspondence: vincent.eijsink@nmbu.no

${ }^{1}$ Faculty of Chemistry, Biotechnology and Food Science, NMBUNorwegian University of Life Sciences, Ås, Norway

Full list of author information is available at the end of the article
}

rare structural motif that is called the "histidine brace" [3, 5]. The histidine brace is part of a solvent-exposed substrate binding surface, which, for LPMOs acting on chitin and cellulose, is characteristically flat $[5,6]$. This spatial configuration reflects the unparalleled ability of LPMOs to act on highly crystalline substrate surfaces, rather than on isolated polysaccharide chains within amorphous regions. By doing so, LPMOs provide a substantial boost to conventional hydrolytic enzymes both in nature and in commercial enzyme cocktails $[7,8]$. Due to their intriguing capabilities and industrial applications, there

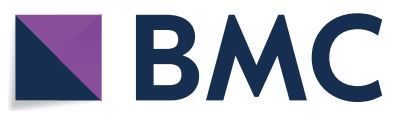

(c) The Author(s) 2021. This article is licensed under a Creative Commons Attribution 4.0 International License, which permits use, sharing, adaptation, distribution and reproduction in any medium or format, as long as you give appropriate credit to the original author(s) and the source, provide a link to the Creative Commons licence, and indicate if changes were made. The images or other third party material in this article are included in the article's Creative Commons licence, unless indicated otherwise in a credit line to the material. If material is not included in the article's Creative Commons licence and your intended use is not permitted by statutory regulation or exceeds the permitted use, you will need to obtain permission directly from the copyright holder. To view a copy of this licence, visit http://creativeco mmons.org/licenses/by/4.0/. The Creative Commons Public Domain Dedication waiver (http://creativecommons.org/publicdomain/ zero/1.0/) applies to the data made available in this article, unless otherwise stated in a credit line to the data. 
is considerable interest in discovering new LPMOs and in understanding how to optimally harness the catalytic potential of these enzymes.

LPMOs rely on reducing power to enable the formation of reactive oxygen species that hydroxylate glycosidic bonds at the $\mathrm{C} 1$ - or C4-position [1, 4, 9]. Interestingly, LPMOs can utilize a vast variety of electron donors, including small phenolic compounds and partner enzymes such as cellobiose dehydrogenase [10, 11]. Ascorbic acid is typically used as a reductant in most experimental setups. LPMO reactions were previously thought to involve molecular oxygen, hence the name monooxygenase, but recently, it has been shown that hydrogen peroxide is the preferred co-substrate [12]. $\mathrm{H}_{2} \mathrm{O}_{2}$-driven reactions are orders of magnitude faster than the reactions with oxygen, where the latter tend to be slow, with rates normally being around $1 \mathrm{~min}^{-1}$ or lower. Importantly, the supply of $\mathrm{H}_{2} \mathrm{O}_{2}$ needs to be controlled to avoid enzyme damage due to self-oxidation [12].

In the presence of oxygen, reduced LPMOs are capable of $\mathrm{H}_{2} \mathrm{O}_{2}$ production. This phenomenon was initially described as a futile reaction that occurs in the absence of a substrate [13]. Given the current insights into the role of $\mathrm{H}_{2} \mathrm{O}_{2}$ as the (preferred) co-substrate, it has been suggested that under commonly used standard aerobic conditions, i.e., in the presence of a reductant and with no exogenously added hydrogen peroxide, the rate and yield of the LPMO reaction are determined by the in situ generation of $\mathrm{H}_{2} \mathrm{O}_{2}$ that is produced by the enzyme or in reactions involving the reductant and molecular oxygen [12]. It is worth noting that there is an ongoing debate on whether truly $\mathrm{O}_{2}$-driven LPMO reactions (i.e., reactions that are not coupled to in situ $\mathrm{H}_{2} \mathrm{O}_{2}$ production) can occur at all [14-17].

Importantly, enzyme-independent $\mathrm{H}_{2} \mathrm{O}_{2}$ production can take place in typical LPMO reaction setups, especially if the reaction, next to a reductant such as ascorbic acid, also contains free transition metal ions, such as $\mathrm{Cu}(\mathrm{II})[18,19]$. Such enzyme-independent generation of hydrogen peroxide could lead to a substantial boost of
LPMO activity on polysaccharide substrates [20]. Due to the use of different enzyme preparation methods and/ or reaction conditions, the free copper content of LPMO reactions may vary, which, considering the above, will have repercussions for the reliability and comparability of observed LPMO activities. For example, a significant amount of metal ions may enter the reaction if a contaminated substrate is used, or in case the target enzyme is not sufficiently purified after copper saturation [21].

In this paper, we describe a cellulose-active family 10 (AA10) LPMO, AA10_07, that was discovered by mining the genome of a marine Actinomycete, isolated from the Trondheim fjord, Norway and referred to as "strain P01F09" below. Next to characterizing the activity of this LPMO, we have used this enzyme as a model to study how reductants and free copper affect LPMO activity on cellulose and to study if and how the observed catalytic activity can be linked to production of $\mathrm{H}_{2} \mathrm{O}_{2}$ in the reaction mixture. Our results demonstrate that ascorbatedriven LPMO reactions are extremely sensitive to free copper in micromolar concentrations, whereas use of gallic acid as reductant allows for steady and controllable reactions that are almost insensitive to the presence of free copper ions.

\section{Results and discussion}

Identification, sequence and domain structure of AA10_07 Actinomycete strain P01-F09 was isolated from a finger sponge harvested at $60 \mathrm{~m}$ depth near Tautra, an island located within the Trondheim fjord, Norway. In silico mining of the P01-F09 draft genome sequence using LPMO HMM profiles led to the identification of a 1083 bp gene encoding a hypothetical family 10 (AA10) LPMO. The candidate enzyme was named AA10_07 and its sequence was annotated using the Pfam domain prediction server [22]. AA10_07 is a 360-residue protein, comprising a 33-residue signal peptide, a catalytic AA10 domain and a C-terminal cellulose-binding module (CBM2) (Fig. 1). The two AA10_07 domains are connected through a linker rich in proline and threonine. BLAST analysis [23] identified ScLPMO10C (CelS2) [2,

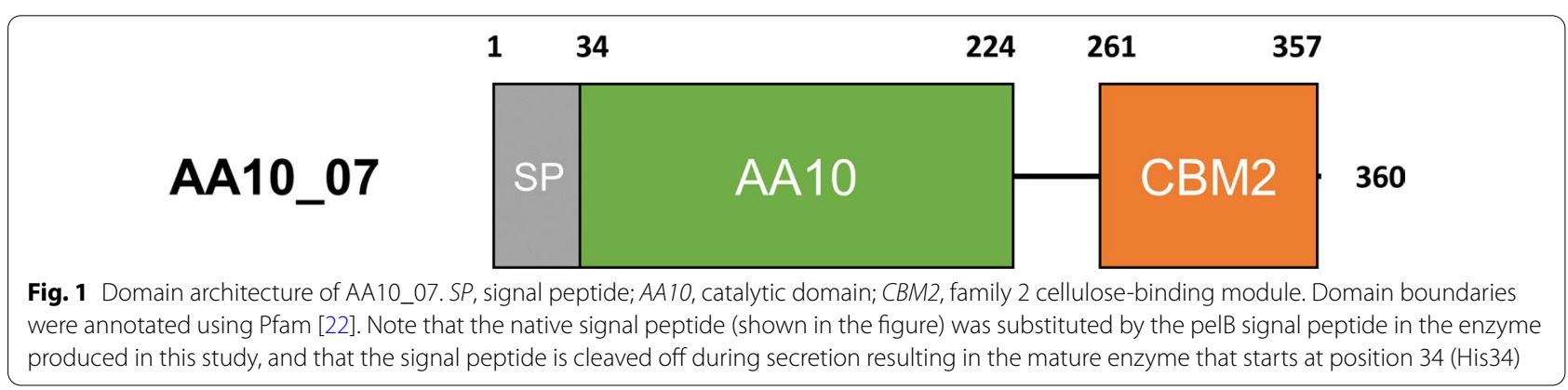


$24]$ as the closest characterised AA10_07 homolog (85.6\% sequence identity between catalytic domains).

\section{Enzyme production and characterization of LPMO activity}

The AA10_07 gene sequence was codon optimized for expression in E. coli and modified to encode the pelB periplasmic localization signal $[25,26]$ instead of the native signal peptide. The gene was cloned into the pET26(b)+ vector and the enzyme was produced in E. coli BL21(DE3) in a soluble form. Starting with a periplasmic extract, AA10_07 was purified to electrophoretic homogeneity by ion-exchange and size-exclusion chromatography. The final yield amounted to approximately $7 \mathrm{mg}$ of purified LPMO per $500 \mathrm{ml}$ of E. coli culture.
To assess AA10_07 activity, $1 \mu \mathrm{M}$ copper-saturated enzyme was incubated with $1 \%(\mathrm{w} / \mathrm{v})$ Avicel in $50 \mathrm{mM}$ sodium phosphate buffer, $\mathrm{pH}$ 6.0, supplied with $1 \mathrm{mM}$ ascorbic acid $\left(30{ }^{\circ} \mathrm{C}, 24 \mathrm{~h}\right)$. The MS spectrum of the reaction mixture (Fig. 2a) shows a product profile that is typical for LPMOs that exclusively oxidize cellulose at $\mathrm{C} 1$. Such oxidation leads to the formation of aldonic acids that give characteristic MS signals due to the formation of sodium and potassium salts. We did not detect any signals that could indicated the formation of double oxidized products, which would appear, albeit at low intensities, if $\mathrm{C} 4$ oxidation would also have occurred [24]. This oxidative regioselectivity of the LPMO reaction was confirmed by chromatographic analysis of products

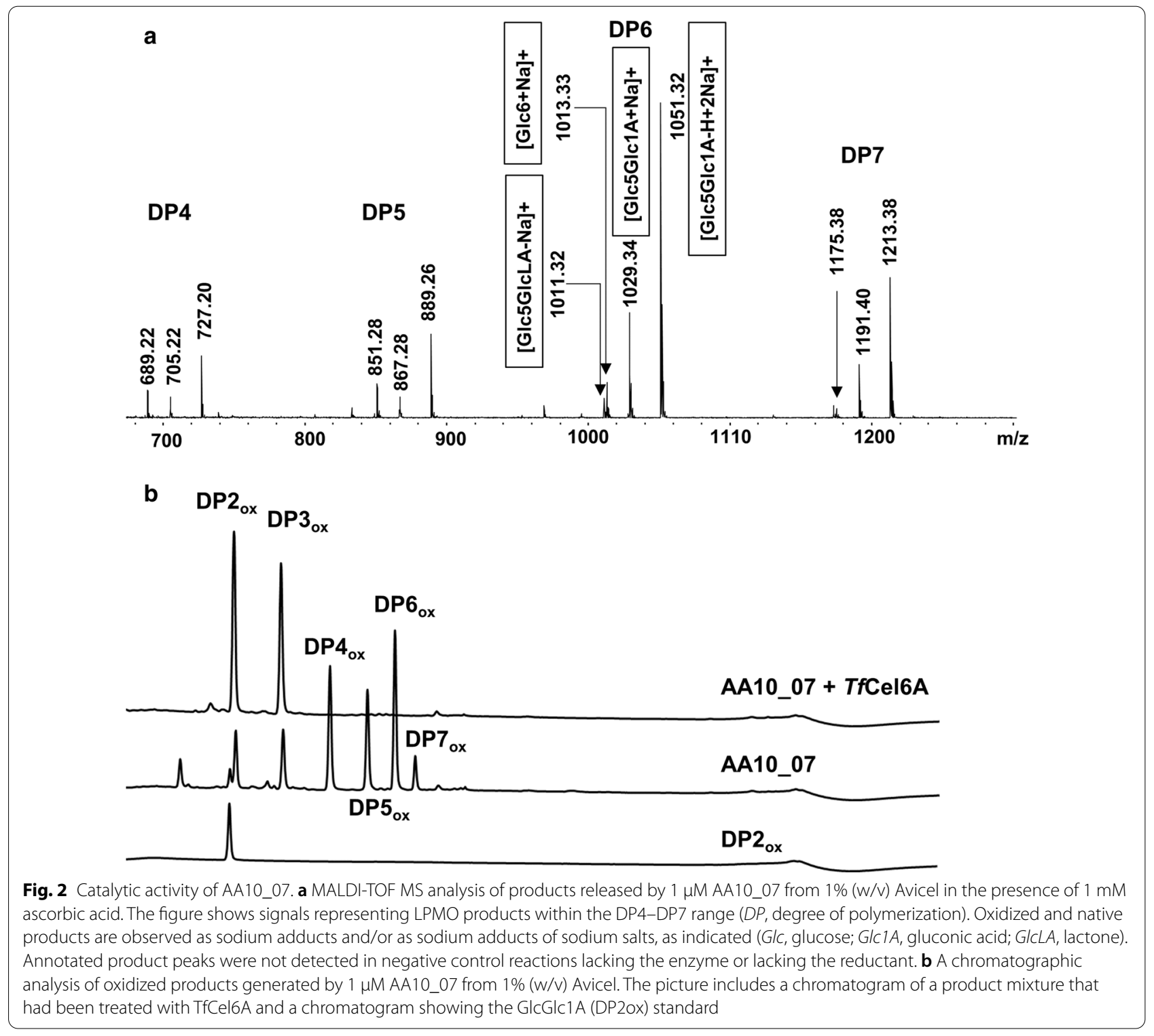


generated from Avicel, which only showed C1-oxidized products (Fig. 2b). Figure $2 \mathrm{~b}$ also shows how the product profile changes after treating the products with TfCel6A endoglucanase; this approach was used for quantification of oxidized sites in the experiments described below.

\section{The impact of the copper saturation protocol on the level of residual free copper in LPMO samples}

Free copper ions will affect LPMO reactions since they promote enzyme-independent $\mathrm{H}_{2} \mathrm{O}_{2}$ production in the presence of ascorbic acid, even when present at submicromolar concentrations ([19-21]; see also Fig. 3). It is reasonable to assume that LPMO preparations vary in terms of the amounts of free copper, due to variations in protein preparation protocols, and this may affect the apparent activity of the LPMOs in certain reaction setups. Copper saturation of the purified LPMO likely is the most critical step, since during that stage a free copper is deliberately introduced into the system.

Here, and in several other studies, copper saturation was achieved by incubating the LPMO with a slight

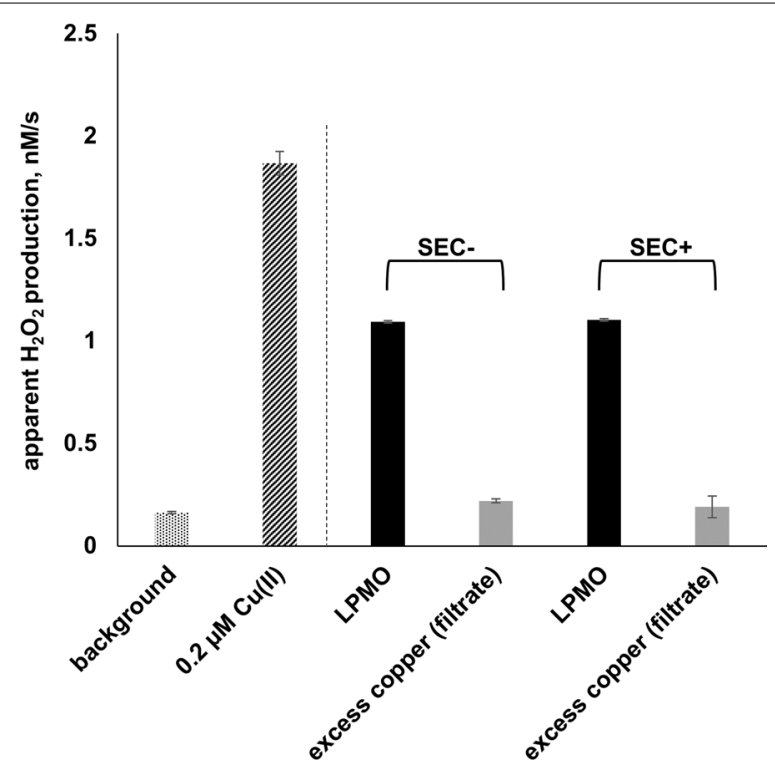

Fig. 3 Apparent hydrogen peroxide production by two batches of AA10_07. The figure shows apparent $\mathrm{H}_{2} \mathrm{O}_{2}$ production by $3 \mu \mathrm{M}$ AA10_07 in 50 mM sodium phosphate buffer, pH 6.0 supplied with $50 \mu \mathrm{M}$ ascorbic acid, $5 \mathrm{U} / \mathrm{ml} \mathrm{HRP}, 100 \mu \mathrm{M}$ Amplex Red and 1\% (v/v) DMSO. SEC-/SEC+ labels indicate the procedure used to remove unbound copper from the LPMO sample after copper saturation. SEC-, gravity-flow desalting column; SEC+, high-resolution SEC chromatography. Excess copper control reactions (grey bars) were set up using protein-free samples, obtained by ultrafiltration. These samples contained the same amount of free copper as the LPMO preparation used in the experiment. The two reactions shown to the left are control reactions: "background", reaction without enzyme;

" $0.2 \mu \mathrm{M} \mathrm{Cu}(\mathrm{II})$ ", reaction without enzyme and with addition of $0.2 \mu \mathrm{M}$ $\mathrm{Cu}(\mathrm{II})$. Error bars indicate standard deviations between triplicates molar surplus of free copper, followed by desalting. We compared AA10_7 samples obtained by two alternative desalting techniques. In one case, unbound copper was removed by fast desalting using a small gravityflow gel filtration column. In the other case, a highresolution preparative SEC column was used instead. The resulting two different batches of copper saturated and desalted AA10_07 showed identical apparent rates of $\mathrm{H}_{2} \mathrm{O}_{2}$ production (Fig. 3) and identical abilities to degrade Avicel (Additional file 1: Fig S1), in reactions with ascorbic acid as the reductant. These observations indicate that both procedures worked equally well in terms of removing free copper.

The copper content of the resulting enzyme preparations was assessed in two manners. Protein-free fractions ("filtrates") produced from these LPMO samples by ultrafiltration did not promote $\mathrm{H}_{2} \mathrm{O}_{2}$ production in a reaction with ascorbic acid, whereas added copper in concentrations as low as $0.2 \mu \mathrm{M}$ did (Fig. 3), indicating that the levels of residual copper were low in both enzyme samples. To confirm this conclusion, both LPMO samples were subjected to ICP-MS analysis. The results indicated the presence of $0.98 \pm 0.18 \mu \mathrm{M}$ and $0.90 \pm 0.14 \mu \mathrm{M}$ total copper in $1 \mu \mathrm{M}$ solutions of gravity flow-desalted and SEC-treated LPMO, respectively. These ICP-MS results are compatible with the notion that the LPMOs were copper saturated, whereas the amounts of free copper were negligible. Finally, the copper content of Avicel was determined by ICPMS showing that only negligible amounts of this metal were present $(<49 \mathrm{ng}$ copper per $1 \mathrm{~g}$ of substrate, corresponding to less than $10 \mathrm{nM}$ in reactions with $1 \%(\mathrm{w} / \mathrm{v})$ Avicel).

\section{Comparison of ascorbic acid and gallic acid in LPMO reactions with Avicel}

Next, we assessed the capacity of gallic acid to drive the oxidation of cellulose by AA10_07. The LPMO reaction supplied with $1 \mathrm{mM}$ gallic acid was more efficient than the reaction supplied with $1 \mathrm{mM}$ ascorbic acid (Fig. 4a). Both reactions were remarkably slow (approximately $0.06 \mathrm{~min}^{-1}$ in the presence of ascorbic acid and $0.2 \mathrm{~min}^{-1}$ in the presence of gallic acid) with almost linear progress within the $24 \mathrm{~h}$ of the experiment.

To verify that the LPMO was catalytically competent and that $\mathrm{H}_{2} \mathrm{O}_{2}$ speeds up the reaction, a control experiment with externally added $\mathrm{H}_{2} \mathrm{O}_{2}$ was conducted, which showed an increase in the initial substrate oxidation rate by two orders of magnitude and, as expected under these conditions, rapid inactivation, regardless of whether the reductant was ascorbic acid or gallic acid (Fig. 4b; note that the $X$-axis has a minutes time scale). 


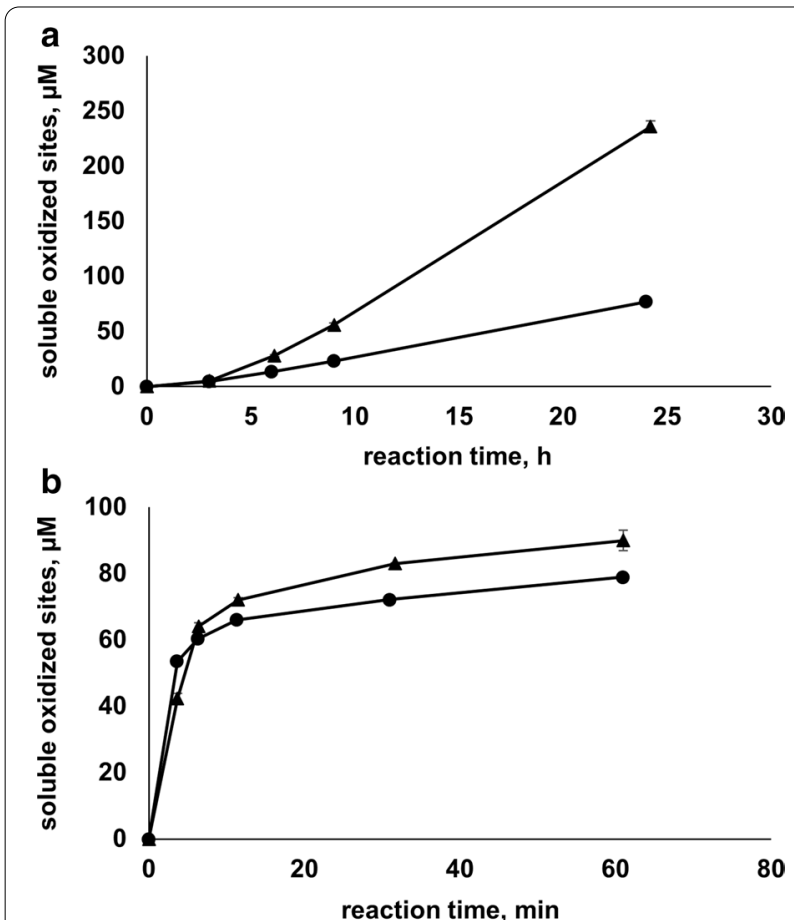

Fig. 4 Cellulose solubilisation by AA10_07 in the presence of ascorbic acid or gallic acid. The figure shows the release of oxidised products in LPMO reactions (1 $\mu \mathrm{M}$ AA10_07 in 50 mM sodium phosphate buffer, $\left.\mathrm{pH} 6.0,30^{\circ} \mathrm{C}\right)$ with $1 \%(\mathrm{w} / \mathrm{v})$ Avicel that were carried out in the absence of hydrogen peroxide (a) or in the presence of $200 \mu \mathrm{M} \mathrm{H}_{2} \mathrm{O}_{2}$ (b) using $1 \mathrm{mM}$ ascorbic acid (circular markers) or $1 \mathrm{mM}$ gallic acid (triangle markers) as a reductant. Error bars indicate standard deviations between triplicates. Note that $\mathbf{a}, \mathbf{b}$ feature different time scales. Product accumulation was not observed in control reactions with substrate and reductant or in reactions with substrate, reductant and $\mathrm{H}_{2} \mathrm{O}_{2}$

\section{Apparent $\mathrm{H}_{2} \mathrm{O}_{2}$ production in reactions with $L P M O$, free copper and $50 \mu \mathrm{M}$ reductant}

To further investigate the effects of free copper, we assessed $\mathrm{H}_{2} \mathrm{O}_{2}$ production in a series of reactions with various amounts of $\mathrm{Cu}(\mathrm{II}) \mathrm{SO}_{4}$ in the presence of two commonly used LPMO reductants, ascorbic acid and gallic acid. Of note, to reduce complications due to reactions between HRP and the reductant (see below), the reductant concentrations typically used in the HRP/Amplex Red $\mathrm{H}_{2} \mathrm{O}_{2}$ assay are much lower (e.g. $50 \mu \mathrm{M}$; [13, 27]) than those typically used in LPMO reactions with substrate (e.g. $1 \mathrm{mM}$ ). The results of the standard $\mathrm{H}_{2} \mathrm{O}_{2}$ assay (Fig. 5) show that sub-micromolar concentrations of free copper increased the apparent rate of $\mathrm{H}_{2} \mathrm{O}_{2}$ production in reactions with $50 \mu \mathrm{M}$ ascorbic acid. Even the reaction with only $0.2 \mu \mathrm{M}$ free copper gave a higher apparent $\mathrm{H}_{2} \mathrm{O}_{2}$ production rate than a reaction lacking free copper but containing $3 \mu \mathrm{M}$ copper-loaded AA10_7. It is noteworthy that these results may be taken to suggest that

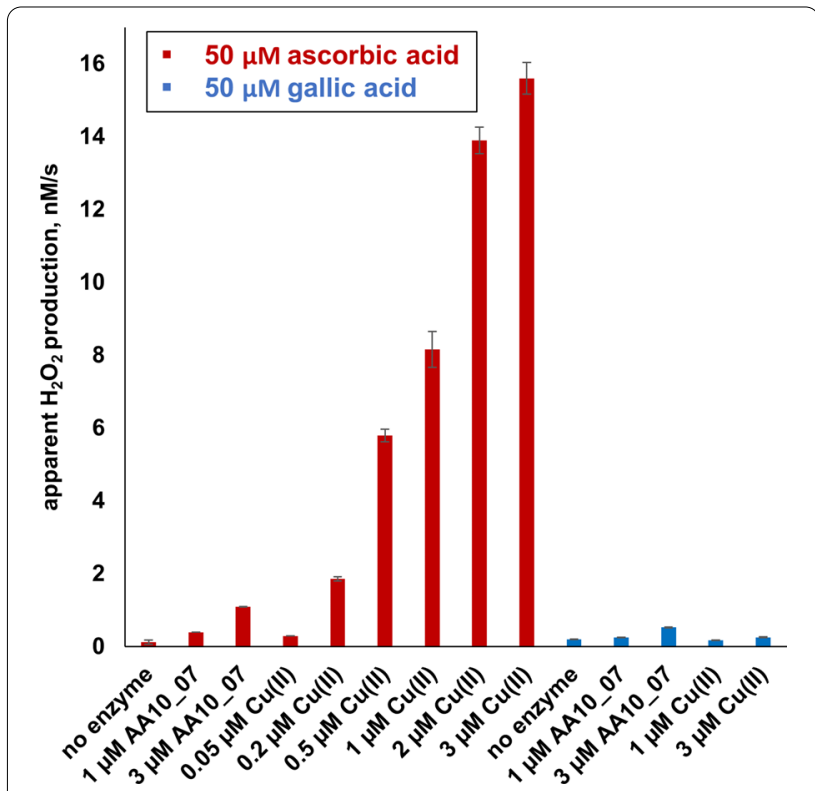

Fig. 5 Apparent $\mathrm{H}_{2} \mathrm{O}_{2}$ production in reactions with free copper and $50 \mu \mathrm{M}$ ascorbic acid or gallic acid. All experiments were carried out in $50 \mathrm{mM}$ sodium phosphate buffer, $\mathrm{pH} 6.0$, at $30^{\circ} \mathrm{C}$. The rates of $\mathrm{H}_{2} \mathrm{O}_{2}$ production by AA10_07 in the presence of $50 \mu \mathrm{M}$ ascorbic acid or $50 \mu \mathrm{M}$ gallic acid are given for reference. The experiment with $0.2 \mu \mathrm{M}$ $\mathrm{Cu}(\mathrm{II})$ is also shown in Fig. 3. Reaction mixtures contained $5 \mathrm{U} / \mathrm{ml} \mathrm{HRP,}$ 100 MM Amplex Red and approximately 1\% (v/v) DMSO. Error bars indicate standard deviations between triplicates

the LPMO protects reduced copper from reacting with molecular oxygen. Similar experiments with $50 \mu \mathrm{M}$ gallic acid showed different results. The apparent initial rate of $\mathrm{H}_{2} \mathrm{O}_{2}$ formation by $3 \mu \mathrm{M}$ AA10_07 in the presence of $50 \mu \mathrm{M}$ gallic acid amounted to $0.53 \mathrm{nM} / \mathrm{s}$, which is two times lower compared to the reaction with ascorbic acid (Fig. 5). Strikingly, hydrogen peroxide accumulation in the presence of free copper and gallic acid was very low compared to similar reactions with ascorbate (Fig. 5). For example, in large contrast to the results obtained with ascorbic acid, the apparent $\mathrm{H}_{2} \mathrm{O}_{2}$ production rate in the reaction with $3 \mu \mathrm{M}$ free copper and gallic acid was not higher than the one observed with LPMO and gallic acid under the same conditions. The observed low reactivity of free copper in the presence of gallic acid is in agreement with electron paramagnetic resonance data [28] showing that gallic acid is likely to form complexes with $\mathrm{Cu}$ (II) rather than reducing it.

\section{Apparent $\mathrm{H}_{2} \mathrm{O}_{2}$ production in the presence of $1 \mathrm{mM}$ reductant}

The experiments with AA10_07 and gallic acid revealed lower apparent $\mathrm{H}_{2} \mathrm{O}_{2}$ production rates compared to the similar setups with ascorbate. However, the LPMO catalytic rate on Avicel was significantly higher in the 
presence of gallic acid, which is surprising if one accepts the premise that generation of $\mathrm{H}_{2} \mathrm{O}_{2}$ limits the reaction.

In search of an explanation for this paradoxical finding, it is important to consider the limitations of the HRP/ Amplex Red assay [29]. The assay is based on single electron oxidation of Amplex Red by HRP in the presence of $\mathrm{H}_{2} \mathrm{O}_{2}$ as a co-substrate [30]. This oxidation leads to the formation of two Amplex Red radicals, which then react to form one molecule of highly chromogenic resorufin and one molecule of Amplex Red. It was previously shown that addition of ascorbic acid leads to repression of the resorufin signal [15], likely due to reduction of Amplex Red radicals back to Amplex Red [30] and/or the ability of HRP to engage in a side-reaction with ascorbate that removes $\mathrm{H}_{2} \mathrm{O}_{2}$ from the system in a way that is uncoupled to resorufin formation [31]. There is evidence that other redox-active compounds may also influence the HRP/Amplex Red assay in a similar fashion [32, 33]. It is thus conceivable that the different apparent $\mathrm{H}_{2} \mathrm{O}_{2}$ production rates for ascorbic acid and gallic acid relate to varying degrees of signal repression. To test this hypothesis, we carried out the HRP/Amplex Red assay using different concentrations of $\mathrm{H}_{2} \mathrm{O}_{2}$ in the presence or absence of $50 \mu \mathrm{M}$ ascorbic acid or gallic acid. This experiment indicated that gallic acid supresses the resorufin signal to approximately same extent as ascorbic acid (Additional file 1: Fig. S2).

We then asked the question whether the discrepancy between apparent $\mathrm{H}_{2} \mathrm{O}_{2}$ production rates and the observed LPMO activities in reactions with Avicel could be due to the largely different reductant concentrations in these two experiments. While low reductant concentrations are commonly used in the $\mathrm{H}_{2} \mathrm{O}_{2}$ production assay, for reasons discussed above, experiments with $1 \mathrm{mM}$ reductant are rare [34]. Thus, we carried out the HRP/Amplex Red assay using various concentrations of hydrogen peroxide in the presence of $1 \mathrm{mM}$ ascorbic acid or gallic acid, which showed that the resorufin signal repression increased only marginally compared to the previous measurement with $50 \mu \mathrm{M}$ reductant (Additional file 1: Fig S2). Thus, measurements of $\mathrm{H}_{2} \mathrm{O}_{2}$ production in reactions with $1 \mathrm{mM}$ reductant seemed feasible.

Therefore, the HRP/Amplex Red assay was performed again in the presence of $1 \mathrm{mM}$ ascorbic acid or $1 \mathrm{mM}$ gallic acid, together with various amounts of LPMO and free copper (Fig. 6a, b). Apparent hydrogen peroxide accumulation rates were corrected for resorufin signal repression using $\mathrm{H}_{2} \mathrm{O}_{2}$ standard curves obtained in the presence of reductants. In this setup, the $\mathrm{H}_{2} \mathrm{O}_{2}$ production rate by $1 \mu \mathrm{M}$ AA10_07 was approximately 2.3 times higher with gallic acid compared to ascorbic acid. Assuming that generation of $\mathrm{H}_{2} \mathrm{O}_{2}$ limits the reaction, the higher $\mathrm{H}_{2} \mathrm{O}_{2}$ production level observed

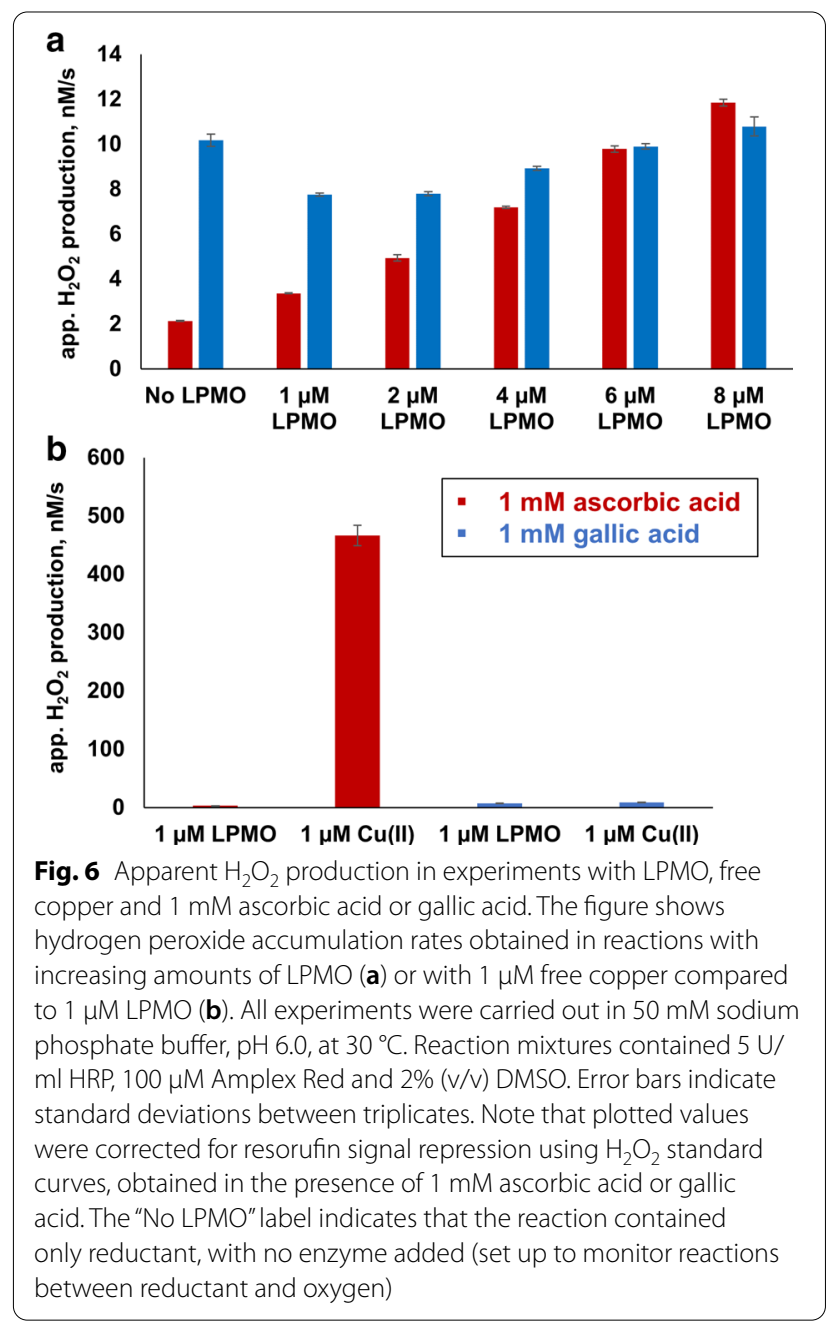

in the reaction with $1 \mathrm{mM}$ gallic acid is in agreement with Avicel degradation data (Fig. 4a) showing that $1 \mu \mathrm{M}$ AA10_07 was most efficient when using gallic acid as reductant. Quantitative comparison of the Avicel degradation data (Fig. 4a) and the $\mathrm{H}_{2} \mathrm{O}_{2}$ production data (Fig. 6a) indicates that the production rate of soluble oxidized products is roughly half of the $\mathrm{H}_{2} \mathrm{O}_{2}$ production rate, which makes sense considering that a considerable fraction of the oxidized sites will remain attached to the insoluble substrate.

Strikingly, when using $1 \mathrm{mM}$ ascorbic acid concentration, $\mathrm{H}_{2} \mathrm{O}_{2}$ production by $1 \mu \mathrm{M}$ free copper was two orders of magnitude higher compared to $1 \mu \mathrm{M}$ LPMO, whereas $\mathrm{H}_{2} \mathrm{O}_{2}$ production in the reaction with free copper and gallic acid was minimal, also at this higher reductant concentration (Fig. 6b). Clearly, in standard LPMO reactions with $1 \mathrm{mM}$ ascorbic acid, the effect of free copper may be considerable, whereas such a copper effect could be less or even absent in reactions with $1 \mathrm{mM}$ gallic acid. This is addressed further below. 
One key question is to what extent the enzyme plays a role in the generation of hydrogen peroxide in the LPMO reaction. Figure $6 \mathrm{a}$ shows that the $\mathrm{H}_{2} \mathrm{O}_{2}$ accumulation rates depended on the enzyme concentration, and that this dependency was stronger for ascorbic acid than for gallic acid. An eightfold increase in LPMO concentration (from 1 to $8 \mu \mathrm{M}$ ) resulted in 3.5 times higher $\mathrm{H}_{2} \mathrm{O}_{2}$ accumulation rates for ascorbic acid, whereas the increase was only a modest and 1.4-fold for gallic acid. In the case of ascorbic acid, the reaction with the lowest LPMO concentration $(1 \mu \mathrm{M})$ generated more $\mathrm{H}_{2} \mathrm{O}_{2}$ than a reaction without enzyme. In contrast, for gallic acid, the experiment without enzyme gave higher hydrogen peroxide levels than the experiments with 1-6 $\mu \mathrm{M}$ enzyme, which may indicate that, in the absence of cellulose substrate, AA10_07 engages in side-reactions that consume $\mathrm{H}_{2} \mathrm{O}_{2}$ and involve gallic acid (or products of gallic acid oxidation). Such reactions are not entirely hypothetical, since it is well known that LPMOs can carry out peroxygenation reactions of small molecules. Breslmayr et al. have shown that after being reduced by 2,6-dimethoxyphenol, LPMOs can oxidize the hydrocoerulignone that is formed by dimerization of two 2,6-dimethoxyphenol radicals in an $\left(\mathrm{H}_{2} \mathrm{O}_{2}\right.$-consuming) peroxygenation reaction [35]. Similar reactions could occur with dimers of gallic acid that are likely to emerge upon its oxidation [36].

Overall, our results suggest that the amount of hydrogen peroxide produced by $1 \mu \mathrm{M}$ LPMO supplied with $1 \mathrm{mM}$ gallic acid is low (Fig. 6a), compared to the amount of $\mathrm{H}_{2} \mathrm{O}_{2}$ generated by the enzyme-independent reaction between reductant and oxygen. In other words, the autooxidation of $1 \mathrm{mM}$ gallic acid is likely to fuel LPMO reactions on Avicel in our setups. In the case of ascorbic acid, both the LPMO and the reductant contribute to generation of $\mathrm{H}_{2} \mathrm{O}_{2}$, at least in the absence of an LPMO substrate (see below).

\section{Effect of the LPMO concentration on degradation of Avicel}

To obtain further insight into factors that limit the LPMO reaction under typical LPMO assay conditions, without depending on the HRP/Amplex Red assay, we carried out a series of LPMO reactions with Avicel (Fig. 7, Additional file 1: Fig. S3) in the presence of $1 \mathrm{mM}$ ascorbic acid or $1 \mathrm{mM}$ gallic acid using a wide range of AA10_07 concentrations $(0.01-8 \mu \mathrm{M})$. In light of the $\mathrm{H}_{2} \mathrm{O}_{2}$ accumulation data shown in Fig. 6a, and assuming that enzyme-independent generation of $\mathrm{H}_{2} \mathrm{O}_{2}$ limits the reaction, one could expect limited effects of the LPMO concentration on the cellulose degradation rate, in particular for reactions with gallic acid.

Such behaviour was indeed observed in the experiment with $1 \mathrm{mM}$ gallic acid, (Fig. 7, Additional file 1: Fig. S3). Within the enzyme concentration range of $0.1 \mu \mathrm{M}$

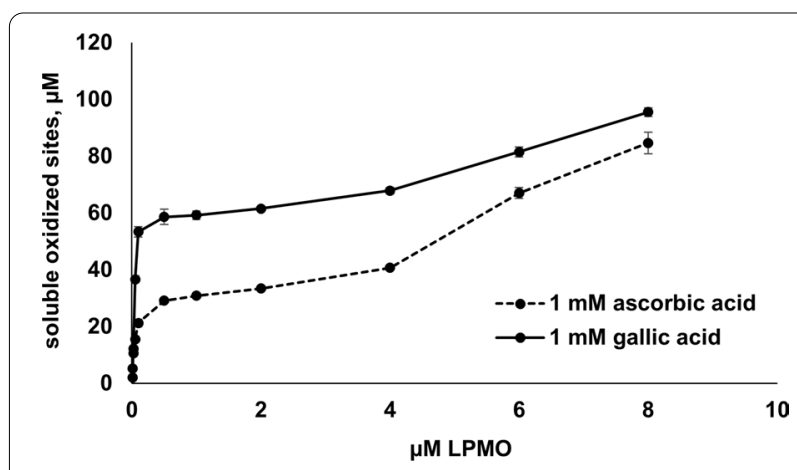

Fig. 7 Avicel solubilisation by increasing amounts of AA10_07 in the presence of ascorbic acid or gallic acid. The figure shows the release of oxidised products from $1 \%(\mathrm{w} / \mathrm{v})$ Avicel in $9 \mathrm{~h}$ reactions with 0.01-8 $\mathrm{MM}$ AA10_07 in 50 mM sodium phosphate buffer, $\mathrm{pH}$ $6.0,30^{\circ} \mathrm{C}$. The experiments were carried out using $1 \mathrm{mM}$ ascorbic acid (dashed line) or $1 \mathrm{mM}$ gallic acid (solid line) as a reductant. Error bars indicate standard deviations between triplicates. Note that the plotted data are derived from LPMO progress curves shown in Additional file 1: Fig. S3. All these reactions displayed linear behavior, except for experiments with $0.01 \mu \mathrm{M}$ or $0.025 \mu \mathrm{M}$ enzyme and gallic acid

to $4 \mu \mathrm{M}$, the enzyme dose had almost no effect on the rate of cellulose degradation. Note that progress curves (Additional file 1: Fig. S3) obtained for the reactions with 0.1-4 $\mu \mathrm{M}$ LPMO were linear, showing that the amount of substrate was not limiting these reactions.

Further increase of the LPMO dose resulted in a gradual increase in the rate of substrate oxidation, indicating that the enzyme's contribution to $\mathrm{H}_{2} \mathrm{O}_{2}$ production becomes significant at higher enzyme concentrations. At very low enzyme concentrations $(<0.1 \mu \mathrm{M})$, there was a strong dose-dependency, most likely due to the fact that there was not enough enzyme to consume $\mathrm{H}_{2} \mathrm{O}_{2}$ effectively (i.e., the reaction was limited by the enzyme and not by hydrogen peroxide). The experiment with $1 \mathrm{mM}$ ascorbic acid revealed the same low dependency of the cellulose oxidation rate on the LPMO concentration in the $0.1-4 \mu \mathrm{M}$ range (Fig. 7, Additional file 1: Fig. S3). This observation was unexpected if one considers the $\mathrm{H}_{2} \mathrm{O}_{2}$ accumulation data (Fig. 6a), which suggest that, in reactions with ascorbic acid, the LPMO contribution to overall hydrogen peroxide generation is considerable. One obvious, but nevertheless speculative, explanation would be that binding of the LPMO to the substrate reduce the enzyme's ability to generate $\mathrm{H}_{2} \mathrm{O}_{2}[13,15,37]$. Interestingly, at the higher LPMO concentrations, there was a dose-response effect that was more pronounced compared to the similar reactions with gallic acid, which is in agreement with the $\mathrm{H}_{2} \mathrm{O}_{2}$ accumulation data of Fig. 6a. Overall, our results indicate that under most commonly used reaction conditions, oxidation of the reductant by 
$\mathrm{O}_{2}$ is a major source of $\mathrm{H}_{2} \mathrm{O}_{2}$ that fuels cellulose degradation by AA10_07.

\section{The effect of free copper on LPMO reactions with Avicel} Digging further into interactions between enzyme, free copper and electron donors, we carried out degradation reactions with Avicel using $1 \mathrm{mM}$ ascorbic acid or $1 \mathrm{mM}$ gallic acid as the reductant. Various amounts of free copper were added to the reactions to mimic copper contamination and to vary the rate of enzyme-independent production of $\mathrm{H}_{2} \mathrm{O}_{2}$. The addition of $\mathrm{Cu}$ (II) to reactions with ascorbic acid resulted in a copper dose-dependent increase in LPMO activity (Fig. 8a), which is to be expected considering the high rates of $\mathrm{H}_{2} \mathrm{O}_{2}$ production in reactions with free copper and $1 \mathrm{mM}$ ascorbic acid (Fig. 6b). Comparison of Figs. $4 \mathrm{a}$ and $8 \mathrm{a}$ shows that a $1 \mathrm{~h}$ reaction in the presence of $1 \mu \mathrm{M} \mathrm{Cu}$ (II)SO $\mathrm{SO}_{4}$ and ascorbic acid (Fig. 8a) yielded more oxidized products than a $24 \mathrm{~h}$ copperfree reaction with the same reductant (Fig. 4a). At $3 \mu \mathrm{M}$ copper, the reaction is even faster, leading to high

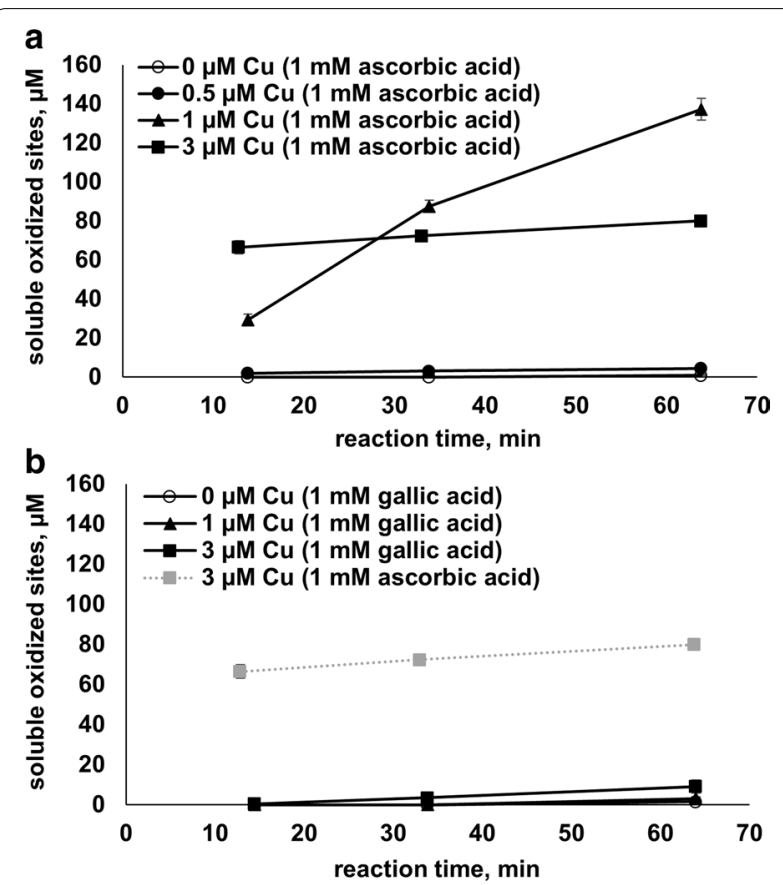

Fig. 8 The effect of free copper on AA10_07 reactions with cellulose in the presence of ascorbic acid or gallic acid. The figure shows progress curves obtained for AA10_07 reactions ( $1 \mu \mathrm{M}$ LPMO in $50 \mathrm{mM}$ sodium phosphate buffer, $\mathrm{pH} 6.0,30^{\circ} \mathrm{C}$ ) with $1 \%(\mathrm{w} / \mathrm{v})$ Avicel using $1 \mathrm{mM}$ ascorbic acid (a) or $1 \mathrm{mM}$ gallic acid (b) and various concentrations of free copper. Note that $\mathbf{b}$ also features the progress curve obtained with $3 \mu \mathrm{M}$ free copper and $1 \mathrm{mM}$ ascorbic acid, which is shown in $\mathbf{a}$, for reference. Error bars indicate standard deviations between triplicates. Note the different time scale compared to Fig. 4a. Product accumulation was not observed in control reactions with no enzyme, containing substrate, free copper, and reductant product concentrations at the first measuring point, but under these conditions, the enzyme becomes rapidly inactivated, as one would expect if (too) much $\mathrm{H}_{2} \mathrm{O}_{2}$ is produced [12, 20].

On the other hand, the LPMO reaction driven by gallic acid (Fig. 8b) turned out to be essentially insensitive to free copper (up to $3 \mu \mathrm{M} \mathrm{Cu}(\mathrm{II}) \mathrm{SO}_{4}$ ), which is in agreement with the $\mathrm{H}_{2} \mathrm{O}_{2}$ production data (Figs. 5, 6 ) and with the notion that this reductant forms complexes with $\mathrm{Cu}(\mathrm{II})$, thus preventing $\mathrm{Cu}(\mathrm{II})$ from participating in redox reaction in solution [28].

Estimating catalytic rates from the progress curves of Figs. $4 a, 8 a$ shows that introduction of $1 \mu \mathrm{M} \mathrm{Cu}(\mathrm{II})$ to the LPMO reaction fuelled by ascorbate speeded up the reaction by some 50 -fold, which is in the same order of magnitude as the effect of $1 \mu \mathrm{M} \mathrm{Cu}(\mathrm{II})$ on ascorbic aciddriven production of $\mathrm{H}_{2} \mathrm{O}_{2}$ (Fig. 6b). Nevertheless, the LPMO reaction fuelled by ascorbate and in the presence of $1 \mu \mathrm{M} \mathrm{Cu}(\mathrm{II})$ was still much slower and showed less rapid enzyme inactivation (Fig. 8a) compared to the reaction with initial addition of $200 \mu \mathrm{M}$ hydrogen peroxide (Fig. 4b). This observation is not surprising, considering the hydrogen peroxide production data of Fig. $6 \mathrm{~b}$ that show an approximate $\mathrm{H}_{2} \mathrm{O}_{2}$ production rate of $0.5 \mu \mathrm{M} / \mathrm{s}$ for the reaction with $1 \mu \mathrm{M} \mathrm{Cu}$ (II) and $1 \mathrm{mM}$ ascorbic acid. Clearly, despite the effect of free copper, the $\mathrm{H}_{2} \mathrm{O}_{2}$ concentration in the reaction with exogenously added $\mathrm{H}_{2} \mathrm{O}_{2}$ was much higher.

The lack of an effect of low copper concentrations $(<1 \mu \mathrm{M})$ on the ascorbic acid-driven reaction was somewhat unexpected considering the $\mathrm{H}_{2} \mathrm{O}_{2}$ production curves shown in Fig. 5. It is conceivable that the Avicel used in the experiment possesses a weak copperbinding capacity that removes a fraction of free copper from the reaction. It is also possible that the LPMO has secondary (low affinity) copper-binding sites [38]. Finally, it is possible that under the conditions of the Avicel assay, copper and/or $\mathrm{H}_{2} \mathrm{O}_{2}$ engage in side-reactions that may reduce $\mathrm{H}_{2} \mathrm{O}_{2}$ production or increase futile $\mathrm{H}_{2} \mathrm{O}_{2}$ consumption, hiding the copper effect on LPMO activity at the lowest copper concentrations.

The sensitivity of the LPMO reaction to free copper in the presence of ascorbic acid must be taken into account when interpreting previously obtained doseresponse curves for AA10_07 (Fig. 7). It is conceivable that the dependency of the product formation rate on the amount of LPMO observed at high enzyme concentrations $(>4 \mu \mathrm{M})$ is explained by increasing amounts of free copper that are introduced to the reaction together with the enzyme. A control experiment with proteinfree ultrafiltrates of the enzyme stock solutions showed that this was not the case (Additional file 1: Fig. S4). 


\section{Copper bias in previously reported LPMO data}

The Avicel degradation experiments with either ascorbic acid or gallic acid (in the absence of exogenous $\mathrm{H}_{2} \mathrm{O}_{2}$ and free copper) indicate that AA10_07 is a slow enzyme. Early in the reaction, i.e., within the first hour or so, the release of soluble products is close to negligible (Fig. 4a), which is likely due to the fact that in this early phase of the reaction, oxidized products are still polymeric and, thus, not soluble. Frommhagen et al. [39] have pointed out that it takes a while before the same cellulose chain has been cleaved sufficiently many times to generate short, soluble products that are released into solution. Later during the reaction (Fig. 4a), the release of oxidized products over time was close to linear, but very slow, with rates (estimated from Fig. 4a) in the range of 0.06$0.2 \mathrm{~min}^{-1}$. Such rates are common among reported rate estimates for LPMOs [40], but these rates are really low and two orders of magnitude lower than rates obtained in reactions with Avicel that are supplied with exogenous $\mathrm{H}_{2} \mathrm{O}_{2}$, which are higher than $10 \mathrm{~min}^{-1}$ (Fig. 4b).

AA10_07 is a close homolog of the well-studied ScLPMO10C (CelS2; 85.6\% sequence identity between catalytic domains). In previous studies by our group, ScLPMO10C displayed low cellulose oxidation rates $\left(0.1-0.2 \mathrm{~min}^{-1}\right)$ in reactions fuelled by ascorbic acid $[24,41]$, which are comparable to the results obtained here for AA10_07. However, looking back on a larger set of (our own) data, we noted that much higher oxidation rates were observed in other studies while using seemingly comparable conditions, as shown in Table 1 . Importantly, all ScLPMO10C experiments quoted in
Table 1 were based upon similar LPMO production, purification and copper saturation procedures.

Given the fact that all these studies involved ascorbic acid as the reductant, it is reasonable to assume that the observed variations in LPMO activity were caused by different levels of free copper in the reactions (as well as, in some cases, other factors such as $\mathrm{pH}$ and the type of substrate).

Comparison of two in-house produced batches of ScLPMO10C, one freshly prepared and one older batch that had shown "high activity", in the same experiment indeed showed large differences in product yields (Additional file 1: Fig. S5). Most importantly, the difference between the two protein batches disappeared after the most active batch had been subjected to another round of desalting. Quantification of total copper by ICP-MS indicated the presence of $0.9 \pm 0.139 \mu \mathrm{M}$ and $1.7 \pm 0.298 \mu \mathrm{M}$ copper ions in $1 \mu \mathrm{M}$ enzyme solutions of the freshly prepared and the older "active" enzyme batches, thus confirming that the observed activity differences indeed correlated with varying amounts of free copper.

It is worth noting that both ScLPMO10C batches were prepared in the same manner. In both cases (as well as in the other studies featured in Table 1), a gravity-flow desalting column was used to remove excess copper after copper saturation. It is reasonable to assume that the efficiency of the desalting procedure may have varied. The desalting experiments described above show how LPMO preparations devoid of free copper can be prepared and the filtration experiment

Table 1 Cellulose oxidation rates derived from previously reported ScLPMO10C reactions driven by ascorbic acid and molecular oxygen

\begin{tabular}{|c|c|c|c|}
\hline $\begin{array}{l}\text { Approximate } \\
\text { cellulose } \\
\text { oxidation rate }\end{array}$ & Product quantification routine ${ }^{c}$ & Substrate and reaction conditions & References \\
\hline $0.2 \mathrm{~min}^{-1 \mathrm{a}}$ & $\begin{array}{l}\text { DP2ox quantification (HPAEC-PAD) after treatment with } \\
\text { TrCel7A cellobiohydrolase }\end{array}$ & $\begin{array}{l}0.2 \%(\mathrm{w} / \mathrm{v}) \text { PASC, } 20 \mathrm{mM} \text { ammonium acetate buffer, } \mathrm{pH} \\
6.0,40^{\circ} \mathrm{C}, 2 \mathrm{mM} \text { ascorbic acid }\end{array}$ & [24]: Fig. $2 a$ \\
\hline $0.14 \mathrm{~min}^{-1 \mathrm{a}}$ & $\begin{array}{l}\text { DP2ox quantification (HPAEC-PAD) after treatment with } \\
\text { TfCel5A endogluconase }\end{array}$ & $\begin{array}{l}1 \%(\mathrm{w} / \mathrm{v}) \text { Avicel, } 50 \mathrm{mM} \text { sodium phosphate buffer, } \mathrm{pH} \\
6.0,40^{\circ} \mathrm{C}, 1 \mathrm{mM} \text { ascorbic acid }\end{array}$ & [41]: Fig. 2 \\
\hline $6.7 \min ^{-1}$ & $\begin{array}{l}\text { DP2ox + DP3ox quantification (HPAEC-PAD) after treat- } \\
\text { ment with TfCel5A endogluconase }\end{array}$ & $\begin{array}{l}\text { 1\% (w/v) Avicel, } 50 \mathrm{mM} \text { sodium phosphate buffer, } \mathrm{pH} \\
\text { 7.0,40 }{ }^{\circ} \mathrm{C}, 1 \mathrm{mM} \text { ascorbic acid }\end{array}$ & [42]: Fig. 4 \\
\hline $3.4 \mathrm{~min}^{-1 \mathrm{~b}}$ & $\begin{array}{l}\text { DP2ox + DP3ox quantification (HPAEC-PAD) after treat- } \\
\text { ment with TfCel5A endogluconase }\end{array}$ & $\begin{array}{l}\text { 1\% (w/v) Avicel, } 50 \mathrm{mM} \text { sodium phosphate buffer, } \mathrm{pH} \\
\text { 7.0, } 40^{\circ} \mathrm{C}, 1 \mathrm{mM} \text { ascorbic acid }\end{array}$ & [12]: Fig. If \\
\hline $2.5 \min ^{-1 b}$ & $\begin{array}{l}\text { DP2ox + DP3ox quantification (HPAEC-PAD) after treat- } \\
\text { ment with TfCel5A endogluconase }\end{array}$ & $\begin{array}{l}0.5 \% \text { (w/v) PASC, } 50 \mathrm{mM} \text { sodium phosphate buffer, } \mathrm{pH} \\
6.0,40^{\circ} \mathrm{C}, 1 \mathrm{mM} \text { ascorbic acid }\end{array}$ & [43]: Fig. 8 \\
\hline $7.9 \min ^{-1}$ & $\begin{array}{l}\text { DP2ox + DP3ox quantification (HPAEC-PAD) after treat- } \\
\text { ment with TfCel5A endoglucanase }\end{array}$ & $\begin{array}{l}\text { 1\% (w/v) Avicel, } 50 \mathrm{mM} \text { sodium phosphate buffer, } \mathrm{pH} \\
\text { 7.0, } 40^{\circ} \mathrm{C}, 1 \mathrm{mM} \text { ascorbic acid }\end{array}$ & [20]: Fig. $2 a$ \\
\hline
\end{tabular}

a The reported rate is underestimated by approximately twofold due to limitations in product quantification. Only C1-oxidized cellobiose was quantified in the mixture of C1-oxidized cellobiose and C1-oxidized cellotriose. The molar ratio between these products is typically close to 1 in reactions with SCLPMO10C [41]

b No progress curves were reported in the paper meaning that approximate oxidation rates were estimated using single time points

c DP2ox/DP3ox: C1-oxidized cellobiose/cellotriose 
depicted in Fig. 3 provides a simple method to check for free copper that does not depend on the use of an ICP-MS.

\section{Conclusions}

Taken together, our results indicate that the use of ascorbic acid as a reductant in LPMO experiments is not optimal, if reproducibility of kinetic data is considered. Ascorbate-driven reactions are sensitive to micromolar concentrations of free copper due to high levels of copper-catalyzed enzyme-independent $\mathrm{H}_{2} \mathrm{O}_{2}$ production. On the other hand, when using gallic acid as an electron donor, the LPMO progress curves show no strong dependency on free copper in the system (at least up to a $3 \mu \mathrm{M}$ concentration). This is most likely due to complexation of free $\mathrm{Cu}(\mathrm{II})$ by gallic acid, which prevents copper reduction.

Potential sources of free copper in LPMO reactions are numerous. LPMO samples may be contaminated as a result of a copper saturation procedure, in case excess $\mathrm{Cu}$ (II) ions are not completely removed from the system. Other components of typical LPMO reactions, such as the substrate, may also contain small amounts of copper. Notably, copper carry-over may be facilitated by secondary low affinity binding sites on the enzyme, as observed in some crystal structures [38], and by poly-histidine affinity tags, which are known to possess a high affinity for $\mathrm{Cu}$ (II) [44].

Given that ascorbic acid is the most commonly used reductant in the field, it is likely that published LPMO activity data to some extent are biased by the presence of varying and unknown amounts of free copper in the reactions that were conducted. As we illustrate above, this includes some of our own previous work on ScLPMO10C for which we (implicitly) have reported different (higher) catalytic efficiencies which are due to variations in free copper.

The reported sensitivity to free copper is likely not exclusive to LPMO systems that are fuelled by ascorbate and may also apply to reactions with other reductants. For example, it has been established that autoxidation of both L-cysteine and glutathione, compounds that are regularly used as LPMO reductants [1, 11, 45-47], is catalysed by micromolar amounts of free $\mathrm{Cu}$ (II) ions in a manner that leads to the production of hydrogen peroxide $[48,49]$.

On another note, this study presents an illustration of the complex nature and limitations of the HRP/Amplex Red assay (see also [29]). We demonstrate that apparent $\mathrm{H}_{2} \mathrm{O}_{2}$ production rates obtained by this method using low concentrations of reductants (a rather common approach employed in many LPMO studies) may not necessarily describe trends that exist in reactions on cellulose at standard aerobic conditions (i.e., at $\geq 1 \mathrm{mM}$ reductant concentration).

Our data provide insight into multiple mechanisms that may explain why LPMO activity is reductant-dependent. In this paper we show that, in the presence of substrate, hydrogen peroxide generation by $1 \mu \mathrm{M}$ of a family AA10 LPMO is negligible compared to the amounts of $\mathrm{H}_{2} \mathrm{O}_{2}$ produced by the autoxidation of $1 \mathrm{mM}$ ascorbic acid and, in particular, $1 \mathrm{mM}$ gallic acid.

It is worth noting that LPMOs may significantly vary in hydrogen peroxide production and, thus, some enzymes, for example fungal AA9 type LPMOs, may show less dependency on reductant autoxidation. Furthermore, the oxidation of reductants by oxygen (both in the presence and in absence of free copper) is likely to be affected by $\mathrm{pH}$ (these effects are well-described for ascorbate, e.g. $[18,50])$, hence the contribution of this process to overall $\mathrm{H}_{2} \mathrm{O}_{2}$ production may depend on reaction conditions.

All in all, this study sheds light on the complex impact of the reductant on LPMO catalysis. Under commonly used reaction conditions, the large surplus of reductant likely ensures that reduction of the LPMO is not ratelimiting, and the rate of the reaction is determined by the generation of $\mathrm{H}_{2} \mathrm{O}_{2}$, which, at least in the case of cellulose-active AA10s, is dominated by the oxidation of the reductant by oxygen.

\section{Methods \\ Materials}

Chemicals were obtained from Sigma-Aldrich (St. Louis, MO, USA) unless indicated otherwise. Microcrystalline cellulose used in this study was Avicel PH-101. Amplex Red was obtained from Thermo Fisher Scientific (Waltham, MA, USA). $10 \mathrm{mM}$ Amplex Red stock solutions were prepared in DMSO and stored in lightprotected tubes at $-20{ }^{\circ} \mathrm{C}$. Ascorbic acid and gallic acid were stored at $-20{ }^{\circ} \mathrm{C}$ as $100 \mathrm{mM}$ stock solutions in metal-free TraceSELECT water (Honeywell, Charlotte, NC, USA) and DMSO, respectively. Horseradish peroxidase type II (HRP) was stored in $50 \mathrm{mM}$ sodium phosphate buffer, $\mathrm{pH} 6.0$ at $4{ }^{\circ} \mathrm{C}$ (at $100 \mathrm{U} / \mathrm{ml}$ concentration). Tryptone and yeast extract were obtained from Thermo Fisher Scientific (Waltham, MA, USA).

\section{Identification of the LPMO gene}

Strain P01-F09 was isolated from a finger sponge harvested at $60 \mathrm{~m}$ depth near Tautra, an island located within the Trondheim fjord, Norway $\left(063^{\circ} 36^{\prime} 53^{\prime \prime}\right.$ $\mathrm{N}, 010^{\circ} 31^{\prime} 22^{\prime \prime}$ E) on September 22, 2005. Phylogenetic analysis (16 s rRNA) indicated the closest taxonomic neighbour being Streptomyces griseolus (98.8\% sequence identity). Shotgun sequencing of the strain's genome was carried out at BaseClear BV (Leiden, 
Netherlands) using Illumina HiSeq, revealing a genome size of 7,272,225 bp in 910 scaffolds.

Putative LPMO coding sequences within the obtained scaffolds were identified using the hmmscan tool from the HMMER software package version 3.1b2 (http://hmmer.org/) [51]. The Hidden Markov Model (HMM) profiles of all LMPO families were extracted from the dbCAN database [52] (version 7 at the time of the analysis), available from the dbCAN website (http://bcb.unl.edu/dbCAN2/). The analysis led to the identification of a seemingly complete gene putatively encoding an AA10 (family 10) LPMO, here referred to as AA10_07. The AA10_07 sequence has been submitted to Genbank under Accession number MT882343.

\section{Protein expression}

The AA10_07-encoding gene (GenBank accession number MT882343) was codon optimized for expression in Escherichia coli and synthesized by GenScript (Piscataway, NJ, USA). The resulting synthetic DNA contained a $66 \mathrm{bp}$ leader sequence, encoding for the pelB signal peptide, followed by the $L P M O$ gene (residue 34-360). The gene construct was cloned into the pET-26(b)+expression vector (Merck, Darmstadt, Germany) using NdeI/XhoI restriction sites and sequenced (Sanger sequencing) by GenScript (Piscataway, NJ, USA).

An AA10_07 expression strain was established by heat-shock transformation of BL21 (DE3) competent cells (Invitrogen, Carlsbad, USA) with the expression vector, according to the supplier's protocol. The transformed cells were grown in LB medium at $37{ }^{\circ} \mathrm{C}$ for $1 \mathrm{~h}$, and then plated on LB agar medium with $50 \mu \mathrm{g} /$ $\mathrm{ml}$ kanamycin, followed by incubation overnight at the same temperature. A single colony was picked from the agar plate to inoculate $500 \mathrm{ml}$ of Terrific Broth (TB) medium supplied with $50 \mu \mathrm{g} / \mathrm{ml}$ kanamycin. The resulting culture was incubated for $24 \mathrm{~h}$ at $30{ }^{\circ} \mathrm{C}$ in a LEX-24 Bioreactor (Harbinger Biotechnology \& Engineering, Markham, Canada) using compressed air for aeration and mixing. Under the conditions used here, there was a considerable level of basal expression ("promotor leakage"), hence no IPTG induction was necessary.

The cells were harvested by centrifugation $(6000 \times g$ for $10 \mathrm{~min}$ ) at $4{ }^{\circ} \mathrm{C}$, using a Beckman Coulter centrifuge (Brea, CA, USA), and then subjected to periplasmic extraction by osmotic shock as described previously [53]. The periplasmic extracts were sterilized by filtration through a sterile $0.22 \mu \mathrm{m}$ syringe filter (Sarstedt, Nümbrecht, Germany) and stored at $4{ }^{\circ} \mathrm{C}$ prior to purification of the LPMO.

\section{Protein purification}

AA10_07 was purified from a periplasmic extract using ion-exchange chromatography with a HiTrap ${ }^{\mathrm{TM}}$ DEAE Sepharose FF $5 \mathrm{ml}$ column (GE Healthcare, Chicago, USA). The enzyme was eluted using a linear gradient of $\mathrm{NaCl}(0-500 \mathrm{mM})$ in the starting buffer, which was $50 \mathrm{mM}$ Tris- $\mathrm{HCl}, \mathrm{pH}$ 7.5. Chromatography fractions were analysed by SDS-PAGE (Bio-Rad, Hercules, California, USA). Fractions containing purified enzyme were pooled and concentrated using Vivaspin ultrafiltration tubes with a molecular weight cut-off of $10 \mathrm{kDa}$ (Sartorius, Göttingen, Germany). The concentrated preparations were subjected to size-exclusion chromatography using a HiLoad 16/60 Superdex 75 column (GE Healthcare, Chicago, USA), with $50 \mathrm{mM}$ Tris- $\mathrm{HCl}, \mathrm{pH} 7.5$, containing $200 \mathrm{mM} \mathrm{NaCl}$, which resulted in electrophoretically pure LPMO samples. Protein concentrations were determined by UV-Vis spectroscopy $\left(\mathrm{A}_{280}\right)$ using the theoretical extinction coefficient of AA10_07 (assuming that all pairs of Cys residues form disulphide bonds), as calculated with the ProtParam tool [54].

Copper-saturated enzyme was prepared by co-incubating the purified LPMO with $\mathrm{Cu}(\mathrm{II}) \mathrm{SO}_{4}$ at a 1:3 molar ratio for $30 \mathrm{~min}$, at room temperature in $50 \mathrm{mM}$ Tris$\mathrm{HCl}, \mathrm{pH} 7.5$, containing $200 \mathrm{mM} \mathrm{NaCl}$. Excess copper was removed from the preparation by size-exclusion chromatography on a HiLoad 16/60 Superdex 75 column (as described above) or using a PD MidiTrap G-25 desalting column (GE Healthcare, Chicago, USA) equilibrated with $50 \mathrm{mM}$ sodium phosphate buffer $\mathrm{pH}$ 6.0. To avoid contamination with free copper, the sample size in the desalting step with PD MidiTrap G-25 columns was only $350 \mu \mathrm{l}$ and only the first $1 \mathrm{ml}$ of the eluate (instead of $1.5 \mathrm{ml}$ recommended by the manufacturer) was used in further experiments. In case a HiLoad 16/60 Superdex 75 column was used, subsequent to the gel filtration step, the buffer was exchanged to $50 \mathrm{mM}$ sodium phosphate buffer pH 6.0 using a PD MidiTrap G-25 desalting column. The purified protein samples were stored at $4{ }^{\circ} \mathrm{C}$ until further use.

\section{Assessment of copper content}

The total copper content of selected protein and cellulose samples was determined by inductively coupled plasma mass spectrometry (ICP-MS) using a tandem quadrupole 8800 ICP-QQQ machine (Agilent Technologies), equipped with a collision/reaction cell. The samples were mixed with $70 \%$ ultrapure nitric acid and a multielement internal ICP-MS standard (Inorganic Ventures, Christiansburg, VA, USA). All samples were then autoclaved at $121{ }^{\circ} \mathrm{C}$ in sealed tubes for $30 \mathrm{~min}$ using saturated steam under pressure. Tubes were allowed to cool, 
and the solutions were diluted with deionized 18.2 $\mathrm{M} \Omega$ water to $5 \%(\mathrm{v} / \mathrm{v})$ nitric acid. The ICP-MS instrument was operated in single quadrupole mode using helium as a collision gas to minimize diatomic interferences from plasma or sample. A control standard (Inorganic Ventures, Christiansburg, VA, USA) was analysed in between the protein samples to check and compensate for instrument drift. Calibration curves were prepared prior to protein analysis and the copper concentration was determined according to these curves using Indium as internal standard.

As another method for assessing free copper in enzyme preparations (and its effect on the LPMO reaction), a small volume $(\leq 200 \mu \mathrm{l})$ of LPMO stock solution was subjected to ultrafiltration using a $3 \mathrm{kDa}$ MWCO $1.5 \mathrm{ml}$ ultrafiltration tube (VWR International, Radnor, PA, USA) and centrifugation at $10,000 \mathrm{~g}$ and room temperature for about $3 \mathrm{~min}$. The protein-free filtrate will contain the same concentration of free copper as the LPMO containing retentate. Filtrates and retentates were collected and used in hydrogen peroxide production experiments (see below).

\section{Hydrogen peroxide production}

$\mathrm{H}_{2} \mathrm{O}_{2}$ production assays were based on the approach previously described by Kittl et al. [13]. $90 \mu \mathrm{l}$ sample solutions containing LPMO, horse radish peroxidase (HRP) and Amplex Red in $50 \mathrm{mM}$ sodium phosphate buffer pH 6.0 were pre-incubated in a 96-well microtiter plate for $5 \mathrm{~min}$ at $30{ }^{\circ} \mathrm{C}$. The reactions were initiated by the addition of $10 \mu \mathrm{l}$ of a reductant stock solution. The final concentrations of LPMO, HRP, Amplex Red and reductant were $3 \mu \mathrm{M}, 5 \mathrm{U} / \mathrm{ml}, 100 \mu \mathrm{M}$ and $50 \mu \mathrm{M}$ (or $1 \mathrm{mM}$ ), respectively. For each experiment, control reactions were set up by substituting the LPMO with the same volume of water and/or with the same volume of a protein-free sample ("filtrate"), produced by ultrafiltration of the LPMO stock solution, as described above.

The formation of hydrogen peroxide was monitored by recording the optical absorbance of resorufin (the product generated from Amplex Red by HRP) at $563 \mathrm{~nm}$ over time, at $30{ }^{\circ} \mathrm{C}$, using a Varioscan LUX plate reader (Thermo Fisher Scientific, Waltham, MA, USA). $\mathrm{H}_{2} \mathrm{O}_{2}$ standard solutions were prepared in $50 \mathrm{mM}$ sodium phosphate buffer pH 6.0 and supplied with $5 \mathrm{U} / \mathrm{ml}$ HRP and $100 \mu \mathrm{M}$ Amplex Red to generate a standard curve. Apparent $\mathrm{H}_{2} \mathrm{O}_{2}$ production rates were derived from the initial linear parts of the resorufin production curves.

Hydrogen peroxide production in reactions containing free copper and a reductant (gallic acid or ascorbic acid) was assessed in the same manner as described above, using various concentrations of $\mathrm{Cu}(\mathrm{II}) \mathrm{SO}_{4}$.

\section{LPMO reactions with Avicel}

The LPMO activity on microcrystalline cellulose was studied by setting up reactions with varying amounts of enzyme $(0.05-8 \mu \mathrm{M})$ and $1 \%(\mathrm{w} / \mathrm{v})$ Avicel in $50 \mathrm{mM}$ sodium phosphate buffer $\mathrm{pH}$ 6.0, supplied with $1 \mathrm{mM}$ reductant (gallic acid or ascorbic acid) and varying amounts of $\mathrm{CuSO}_{4}$ or $\mathrm{H}_{2} \mathrm{O}_{2}$. The reactions were carried out in a thermomixer $\left(30^{\circ} \mathrm{C}, 900 \mathrm{RPM}\right)$. Note that LPMO reactions in the presence of gallic acid were set up using a $100 \mathrm{mM}$ stock solution of gallic acid in DMSO. Thus, 1\% (v/v) DMSO was introduced to the reaction mixtures. Control experiments were performed to confirm that $1 \%(\mathrm{v} / \mathrm{v})$ DMSO does not have a significant impact on the LPMO reaction (Additional file 1: Fig S6).

$100 \mu \mathrm{l}$ aliquots were taken at various time points, and the reactions were stopped by immediately separating the enzyme and soluble products from the insoluble substrate by filtration using a 96-well filter plate (Millipore, Burlington, MA, USA), after which the filtrates were stored at $-20{ }^{\circ} \mathrm{C}$. Note that the product profile of AA10_07 (see Fig. 2b) shows a range of shorter to longer oxidized products (DP2-7ox) with DP6ox being the most prominent product. If AA10_07 was capable of degrading soluble cello-oligosaccharides, accumulation of shorter products would be expected, but this is not the case. Thus, the reactions were considered quenched after filtration. For qualitative product analysis, the filtrates were subjected to analytical chromatography without any additional pre-treatment procedures. Prior to quantitative product analysis, the filtrates were incubated at $37^{\circ} \mathrm{C}$, overnight with $1 \mu \mathrm{M}$ in-house produced recombinant Thermobifida fusca GH6 endoglucanase (TfCel6A; [55]) to convert oxidized cello-oligosaccharides to a mixture of oxidized dimers and trimers only.

\section{Product analysis by HPAEC-PAD}

Cellulose degradation products were analysed by highperformance anion-exchange chromatography with pulsed amperometric detection (HPAEC-PAD) using a Dionex ICS5000 system (Thermo Scientific, San Jose, CA, USA) equipped with a CarboPac PA200 analytical column. A stepwise gradient with an increasing amount of eluent $\mathrm{B}$ (eluent B: $0.1 \mathrm{M} \mathrm{NaOH}$ and $1 \mathrm{M} \mathrm{NaOAc}$; eluent $\mathrm{A}: 0.1 \mathrm{M} \mathrm{NaOH}$ ) was applied according to the following program: $0-5.5 \%$ B over $3 \mathrm{~min}, 5.5-15 \%$ B over $6 \mathrm{~min}$, $15-100 \%$ B over $11 \mathrm{~min}, 100-0 \%$ B over $6 \mathrm{~s}, 0 \%$ B over $6 \mathrm{~min}$. The flow rate was $0.5 \mathrm{ml} / \mathrm{min}$. Chromeleon 7.0 software was used for data analysis. C1-oxidized cellooligosaccharide standards with a degree of polymerization of two and three (DP2, DP3) were prepared in-house as described before $[41,56]$. 


\section{Product analysis by MALDI-ToF MS}

Products of Avicel degradation were identified using a matrix-assisted laser desorption/ionization time-offlight (MALDI-ToF) UltrafleXtreme mass spectrometer (Bruker Daltonics GmbH, Bremen, Germany). $1 \mu \mathrm{l}$ of the LPMO reaction mixture was mixed with $2 \mu \mathrm{l}$ of a matrix solution $(9 \mathrm{mg} / \mathrm{ml}$ 2,5-dihydrooxybenzoic acid) on a MTP 384 ground steel target plate (Bruker Daltonics). The plate was air-dried, and the spectral data were acquired using Bruker flexControl software, as described previously [1].

\section{Supplementary Information}

The online version contains supplementary material available at https://doi. org/10.1186/s13068-021-01879-0.

Additional file 1: Fig S1. Cellulose solubilization by two batches of AA10_07. Fig S2. Underestimation of $\mathrm{H}_{2} \mathrm{O}_{2}$ in the presence of ascorbic acid or gallic acid. Fig S3. Cellulose solubilization by increasing amounts of AA10_07 in the presence of ascorbic acid or gallic acid. Fig S4. Cellulose solubilization by 1 MM AA10_07 in the presence of protein-free filtrates. Fig S5. Comparing the activity of two different batches of SCLPMO10C. Fig S6. The effect of DMSO on AA10_07 reactions with cellulose.

\section{Acknowledgements}

We thank Sven Andreas Högfeldt at the Norwegian University of Life Sciences for ICP-MS analysis of LPMO samples.

\section{Author contributions}

AAS did most of the experimental work, analysed data and drafted the manuscript. ZF contributed to designing the study, performed data analysis and edited the manuscript. MS contributed to data interpretation and edited the manuscript. GSN collected and analysed genomic data. AW supervised the project, collected and analysed genomic data and edited the manuscript. A KR and VGHE conceptualized the work, contributed to data interpretation and edited the manuscript. VGHE acquired funding, conceived and supervised the project. All authors read and approved the final manuscript.

\section{Funding}

This work was supported by the Research Council of Norway under Grant no. 269408 (Centre for Digital Life Norway, project OXYMOD).

\section{Availability of data and materials \\ Data supporting the findings of this work are available within the paper and its Additional information file and from the corresponding author upon reasonable request.}

\section{Ethics approval and consent to participate}

Non applicable.

\section{Consent for publication}

Non applicable.

\section{Competing interests}

The authors declare that they have no competing interests.

\section{Author details}

${ }^{1}$ Faculty of Chemistry, Biotechnology and Food Science, NMBU-Norwegian University of Life Sciences, Ås, Norway. ${ }^{2}$ Department of Biotechnology and Nanomedicine, SINTEF Industry, Trondheim, Norway.

Received: 15 November 2020 Accepted: 7 January 2021 Published online: 21 January 2021

\section{References}

1. Vaaje-Kolstad G, et al. An oxidative enzyme boosting the enzymatic conversion of recalcitrant polysaccharides. Science. 2010;330(6001):219-22.

2. Forsberg Z, et al. Cleavage of cellulose by a CBM33 protein. Protein Sci. 2011:20(9):1479-83.

3. Quinlan RJ, et al. Insights into the oxidative degradation of cellulose by a copper metalloenzyme that exploits biomass components. Proc Natl Acad Sci USA. 2011;108(37):15079-84.

4. Phillips $C M$, et al. Cellobiose dehydrogenase and a copper-dependent polysaccharide monooxygenase potentiate cellulose degradation by Neurospora crassa. ACS Chem Biol. 2011;6(12):1399-406.

5. Vaaje-Kolstad G, et al. Structural diversity of lytic polysaccharide monooxygenases. Curr Opin Struct Biol. 2017;44:67-76.

6. Frandsen KE, Lo Leggio L. Lytic polysaccharide monooxygenases: a crystallographer's view on a new class of biomass-degrading enzymes. IUCrJ. 2016;3(6):448-67.

7. Johansen KS. Lytic polysaccharide monooxygenases: the microbial power tool for lignocellulose degradation. Trends Plant Sci. 2016;21(11):926-36.

8. Vaaje-Kolstad G, et al. The non-catalytic chitin-binding protein CBP21 from Serratia marcescens is essential for chitin degradation. J Biol Chem. 2005;280(31):28492-7.

9. Danneels B, Tanghe M, Desmet T. Structural features on the substratebinding surface of fungal lytic polysaccharide monooxygenases determine their oxidative regioselectivity. Biotechnol J. 2019;14(3):e1800211.

10. Kracher $D$, et al. Extracellular electron transfer systems fuel cellulose oxidative degradation. Science. 2016;352(6289):1098-101.

11. Frommhagen $\mathrm{M}$, et al. Lytic polysaccharide monooxygenases from Myceliophthora thermophila C1 differ in substrate preference and reducing agent specificity. Biotechnol Biofuels. 2016;9(1):186.

12. Bissaro $B$, et al. Oxidative cleavage of polysaccharides by monocopper enzymes depends on $\mathrm{H}_{2} \mathrm{O}_{2}$. Nat Chem Biol. 2017;13(10):1123-8.

13. Kittl $R$, et al. Production of four Neurospora crassa lytic polysaccharide monooxygenases in Pichia pastoris monitored by a fluorimetric assay. Biotechnol Biofuels. 2012;5(1):79.

14. Hangasky JA, lavarone AT, Marletta MA. Reactivity of $\mathrm{O}_{2}$ versus $\mathrm{H}_{2} \mathrm{O}_{2}$ with polysaccharide monooxygenases. Proc Natl Acad Sci USA. 2018;115(19):4915-20.

15. Bissaro B, et al. Molecular mechanism of the chitinolytic peroxygenase reaction. Proc Natl Acad Sci USA. 2020;117(3):1504-13.

16. Wang $\mathrm{B}$, et al. Activation of $\mathrm{O}_{2}$ and $\mathrm{H}_{2} \mathrm{O}_{2}$ by lytic polysaccharide monooxygenases. ACS Catal. 2020;10(21):12760-9.

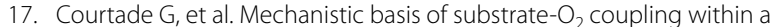
chitin-active lytic polysaccharide monooxygenase: an integrated NMR/ EPR study. Proc Natl Acad Sci USA. 2020;117(32):19178-89.

18. Zhou P, et al. Generation of hydrogen peroxide and hydroxyl radical resulting from oxygen-dependent oxidation of I-ascorbic acid via copper redox-catalyzed reactions. RSC Adv. 2016;6(45):38541-7.

19. Buettner GR, Jurkiewicz BA. Catalytic metals, ascorbate and free radicals: combinations to avoid. Radiat Res. 1996;145(5):532-41.

20. Bissaro B, et al. Controlled depolymerization of cellulose by light-driven lytic polysaccharide oxygenases. Nat Commun. 2020;11(1):890.

21. Eijsink VGH, et al. On the functional characterization of lytic polysaccharide monooxygenases (LPMOs). Biotechnol Biofuels. 2019:12:58.

22. Sonnhammer ELL, Eddy SR, Durbin R. Pfam: a comprehensive database of protein domain families based on seed alignments. Proteins. 1997;28(3):405-20.

23. Altschul SF, et al. Gapped BLAST and PSI-BLAST: a new generation of protein database search programs. Nucleic Acids Res. 1997;25(17):3389-402.

24. Forsberg Z, et al. Structural and functional characterization of a conserved pair of bacterial cellulose-oxidizing lytic polysaccharide monooxygenases. Proc Natl Acad Sci USA. 2014;111(23):8446-51.

25. Lei $\mathrm{SP}$, et al. Characterization of the Erwinia carotovora pelB gene and its product pectate lyase. J Bacteriol. 1987;169(9):4379-83.

26. Zhang $W$, et al. Development an effective system to expression recombinant protein in E. coli via comparison and optimization of signal peptides: expression of Pseudomonas fluorescens BJ-10 thermostable lipase as case study. Microb Cell Fact. 2018;17(1):50.

27. Hegnar $\mathrm{OA}$, et al. pH-dependent relationship between catalytic activity and hydrogen peroxide production shown via characterization of a lytic polysaccharide monooxygenase from Gloeophyllum trabeum. Appl Environ Microbiol. 2019; 85(5):e02612-18. 
28. Severino JF, et al. Is there a redox reaction between $\mathrm{Cu}(\mathrm{II})$ and gallic acid? Free Radic Res. 2011;45(2):115-24.

29. Kont R, et al. Kinetic insights into the peroxygenase activity of celluloseactive lytic polysaccharide monooxygenases (LPMOs). Nat Commun. 2020;11(1):5786.

30. Rodrigues JV, Gomes CM. Enhanced superoxide and hydrogen peroxide detection in biological assays. Free Radic Biol Med. 2010;49(1):61-6.

31. Mehlhorn $\mathrm{H}$, et al. Ascorbate is the natural substrate for plant peroxidases. FEBS Lett. 1996:378(3):203-6.

32. Wang $N$, et al. Quantitative determination of trace hydrogen peroxide in the presence of sulfide using the Amplex Red/horseradish peroxidase assay. Anal Chim Acta. 2017;963:61-7.

33. Jiang S, Penner MH. Overcoming reductant interference in peroxidasebased assays for hydrogen peroxide quantification. J Agric Food Chem. 2017;65(37):8213-9.

34. Loose JS, et al. Activation of bacterial lytic polysaccharide monooxygenases with cellobiose dehydrogenase. Protein Sci. 2016;25(12):2175-86.

35. Breslmayr $\mathrm{E}$, et al. A fast and sensitive activity assay for lytic polysaccharide monooxygenase. Biotechnol Biofuels. 2018;11:79.

36. Tulyathan V, Boulton RB, Singleton VL. Oxygen uptake by gallic acid as a model for similar reactions in wines. J Agric Food Chem. 1989;37(4):844-9.

37. Isaksen T, et al. A C4-oxidizing lytic polysaccharide monooxygenase cleaving both cellulose and cello-oligosaccharides. J Biol Chem. 2014;289(5):2632-42.

38. Borisova AS, et al. Structural and functional characterization of a lytic polysaccharide monooxygenase with broad substrate specificity. J Biol Chem. 2015;290(38):22955-69.

39. Frommhagen $M$, et al. Quantification of the catalytic performance of C1-cellulose-specific lytic polysaccharide monooxygenases. Appl Microbiol Biotechnol. 2018;102(3):1281-95.

40. Bissaro B, et al. Oxidoreductases and reactive oxygen species in conversion of lignocellulosic biomass. Microbiol Mol Biol Rev. 2018;82(4).

41. Bissaro B, et al. Fueling biomass-degrading oxidative enzymes by lightdriven water oxidation. Green Chem. 2016;18(19):5357-66.

42. Courtade G, et al. The carbohydrate-binding module and linker of a modular lytic polysaccharide monooxygenase promote localized celIulose oxidation. J Biol Chem. 2018;293(34):13006-15.

43. Jensen MS, et al. Engineering chitinolytic activity into a cellulose-active lytic polysaccharide monooxygenase provides insights into substrate specificity. J Biol Chem. 2019;294(50):19349-64.
44. Wijekoon CJK, et al. Evaluation of employing poly-lysine tags versus poly-histidine tags for purification and characterization of recombinant copper-binding proteins. J Inorg Biochem. 2016;162:286-94.

45. Frandsen $\mathrm{KEH}$, et al. Identification of the molecular determinants driving the substrate specificity of fungal lytic polysaccharide monooxygenases (LPMOs). J Biol Chem. 2020;Nov 16:jbc.RA120.015545.

46. Chalak A, et al. Influence of the carbohydrate-binding module on the activity of a fungal AA9 lytic polysaccharide monooxygenase on cellulosic substrates. Biotechnol Biofuels. 2019;12:206.

47. Sabbadin F, et al. An ancient family of lytic polysaccharide monooxygenases with roles in arthropod development and biomass digestion. Nat Commun. 2018;9(1):756.

48. Kachur AV, Koch CJ, Biaglow JE. Mechanism of copper-catalyzed autoxidation of cysteine. Free Radic Res. 1999;31(1):23-34.

49. Kachur AV, Koch CJ, Biaglow JE. Mechanism of copper-catalyzed oxidation of glutathione. Free Radic Res. 1998;28(3):259-69.

50. Wilson RJ, Beezer AE, Mitchell JC. A kinetic study of the oxidation of L-ascorbic acid (vitamin C) in solution using an isothermal microcalorimeter. Thermochim Acta. 1995;264:27-40.

51. Finn RD, Clements J, Eddy SR. HMMER web server: interactive sequence similarity searching. Nucleic Acids Res. 2011;39(Web server issue):W29-37.

52. Yin $Y$, et al. dbCAN: a web resource for automated carbohydrateactive enzyme annotation. Nucleic Acids Res. 2012;40(Web server issue):W445-51.

53. Manoil C, Beckwith J. A genetic approach to analyzing membrane protein topology. Science. 1986;233(4771):1403-8.

54. Gasteiger $\mathrm{E}$, et al. Protein identification and analysis tools on the ExPASy Server. In: The proteomics protocols handbook. 2005. p. 571-607.

55. Spezio M, Wilson DB, Karplus PA. Crystal structure of the catalytic domain of a thermophilic endocellulase. Biochemistry. 1993;32(38):9906-16.

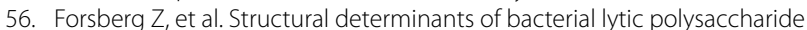
monooxygenase functionality. J Biol Chem. 2018;293(4):1397-412.

\section{Publisher's Note}

Springer Nature remains neutral with regard to jurisdictional claims in published maps and institutional affiliations.
Ready to submit your research? Choose BMC and benefit from:

- fast, convenient online submission

- thorough peer review by experienced researchers in your field

- rapid publication on acceptance

- support for research data, including large and complex data types

- gold Open Access which fosters wider collaboration and increased citations

- maximum visibility for your research: over $100 \mathrm{M}$ website views per year

At BMC, research is always in progress.

Learn more biomedcentral.com/submissions 